PUBLIC DEBT IN DEVELOPING ASIA: A HELP OR HINDRANCE TO GROWTH?

\begin{abstract}
We study the effects of public debt on economic growth using a panel of 25 Asian countries from 1970-2015. Using a collection of panel data models, we find weak evidence in favour of a negative relationship. Our estimates imply that a 10 percent increase in debt predicts declines in growth rates ranging from $0.2 \%$ to $0.4 \%$.
\end{abstract}




\section{PUBLIC DEBT IN DEVELOPING ASIA: A HELP OR HINDRANCE TO GROWTH?}

\section{Introduction}

Developing Asian economies have been the main engine of world growth since the turn of the century. While there has been strong interest in explaining Asia's robust growth performance, little attention has been paid to the influence of public debt on economic growth in the region.

Numerous empirical studies have been published examining the linkage between public debt, with generally mixed results. Several studies that encompass developing economies have found a negative relationship. See for instance, Eberhardt and Presbitero (2015), Égert (2015), Presbitero (2012), Reinhart and Rogoff (2010). On the contrary, other studies have found a positive relationship between public debt and economic growth in developing countries. See Lopes da Veiga, Ferreira-Lopes, and Sequeira (2016), Owusu-Nantwi and Erickson (2016).

The paper by Reinhart and Rogoff (2010) has been especially influential in this space. The research found a weak relationship between public debt and economic growth below $90 \%$ public debt to GDP threshold, whereas above the $90 \%$ threshold economic growth was reduced by around $1.2 \%$ per annum. These findings sparked criticism from Herndon, Ash, and Pollin (2014), Pescatori, Sandri, and Simon (2014), and (Égert, 2015). Inter alia, these authors argued that Reinhart and Rogoff's 90\% threshold was not universal and could vary according to regions and the economic conditions giving rise to the debt.

In our paper we empirically examine public debt and economic growth in the emerging Asian region, based on growth accounting that includes public debt as a possible determinant. Section 
2 explains the data and econometric methods and Section 3 reports the empirical results. The final section concludes the paper and makes policy recommendations.

\section{Data and Methods}

To quantify any empirical link between public debt accumulation and economic growth, we use non-overlapping 5 year panel data for 25 developing Asia countries covering period from 1960-2015 and estimate three alternative econometric models. The models are:

$$
\begin{aligned}
& y_{i t}=\mathbf{x}_{i t}^{\prime} \boldsymbol{\beta}+\lambda_{t}+\gamma D G D P_{i t}+u_{i}+\varepsilon_{i t} \\
& y_{i t}=\alpha_{i}+\lambda_{t}+\mathbf{x}_{i t}^{\prime} \boldsymbol{\beta}+\gamma D G D P_{i t}+\varepsilon_{i t} \\
& y_{i t}=\alpha_{i}+\lambda_{t}+\rho y_{i t-1}+\mathbf{x}_{i t}^{\prime} \boldsymbol{\beta}+\gamma D G D P_{i t}+\varepsilon_{i t}
\end{aligned}
$$

Let $y_{i t}$ denote the real per-capita growth rate of country $i$ in period $t$ and let $D G D P_{i t}$ represent the corresponding debt-to-GDP ratio. A $1 \times k$ vector of other assumedly exogenous controls is given by $\mathbf{x}_{i t}$ and $\varepsilon_{i t}$ is an error term. Parameters $\alpha_{i}, \boldsymbol{\beta}, \lambda_{t}, \rho$ and $\gamma$ are to be estimated.

The key indicator we analyse is the growth rate of real per-capita GDP reflecting improvement in individual living standards over time. This distinguishes our work from others that measure growth in nominal terms (Checherita-Westphal and Rother, 2012; Kumar and Woo, 2015) or do not adjust for population growth (Ghosh, Kim, Mendoza, Ostry, \& Qureshi, 2013).

We included the following exogenous factors as possible drivers of the dependent variable, consistent with Barro and Sala I. Martin (1992):

- The initial real GDP to capture potential dependence on output growth as a function of its level.

- Inflation measured by the consumer price index (CPI).

- Trade openness proxied by the sum of export and imports, as percent of GDP. 
- Population growth per year as a proxy for labour input (Antonakakis, 2014; ChecheritaWestphal and Rother, 2012; Presbitero, 2012)

- Worker share of population (aged between15-64).

- Secondary school education as a human capital indicator, as suggested by Kumar and Woo (2015) and Barro (1996).

- Foreign Direct Investment relative to GDP as capital inflow measure.

- Domestic investment proxied by gross fixed capital formation to GDP ratio (Taylor, 1995)

- Dummies indicating crisis conditions denoting both the 1997 Asian Financial Crisis (AFC) and 2008 Global Financial Crisis (GFC).

- Annual dummies also capture long-run changes in growth rates otherwise uncorrelated with the explanatory variables.

Here equation (1) is a random-effects model, equation (2) allows for fixed-effects, and equation

(3) is a dynamic panel model estimated using difference-GMM (Arellano and Bond, 1991).

Data are collected from numerous international sources, notably the World Bank (World Development Index), International Monetary Fund (World Economic Outlook, International Financial Statistics, Fiscal Monitor), and the Penn World Tables (Feenstra, Inklaar, \& Timmer, 2015).

\section{Empirical Results}

The key results of our paper are presented in Table 1 which shows regression results for the models in Equations (1-3). The key estimates of the impact of public debt on economic growth are presented in the first row. The first two columns give results from the random-effects 
estimations where the coefficients of interest are negative in both cases implying an inverse relationship between growth and debt, although they are not significant at standard levels. The fixed-effects estimates in the central two columns show negative coefficients across both models and significant at in the fully specified model. The dynamic models presented in the final two columns explicitly allow for potential hysteresis in economic growth rates (such that growth spills over period to period). This plausibly implies that economic growth in any given period is not just set by covariates $\mathbf{x}_{i t}$, but by other previous factors (including unobservables).

Table 1 - Effects of Public Debt on Economic Growth

\begin{tabular}{|c|c|c|c|c|c|c|}
\hline VARIABLES & (1) & (2) & (3) & (4) & $(5)$ & (6) \\
\hline Public Debt to GDP & -0.002 & -0.014 & $-0.020 * *$ & -0.021 & $-0.040 * * *$ & -0.030 \\
\hline Trade Openness & 0.002 & & -0.015 & & -0.023 & \\
\hline School Enrolments & -0.007 & & -0.025 & & -0.008 & \\
\hline Population Growth & -0.346 & & -0.857 & & $-0.778 *$ & \\
\hline Foreign Investment Ratio & 0.069 & & 0.028 & & 0.106 & \\
\hline Domestic Investment Ratio & $0.137 * * *$ & & $0.103 * *$ & & $0.116^{* * *}$ & \\
\hline Inflation & -0.015 & & -0.017 & & -0.023 & \\
\hline Working population & $0.195 * * *$ & & -0.023 & & -0.047 & \\
\hline Crisis dummy & -0.157 & & -0.613 & & 0.008 & \\
\hline InitialGDP $(\log )$ & $-1.090 *$ & & 0.452 & & 0.248 & \\
\hline Dum 60-64 & -0.520 & 0.380 & 0.095 & $0.231 * * *$ & 0.158 & 0.123 \\
\hline Dum 65-69 & & 1.770 & & & & \\
\hline Dum 70-74 & & 2.152 & & 0.591 & & \\
\hline Dum 74-79 & -3.041 & 1.420 & & 0.061 & & $-1.096^{*}$ \\
\hline Dum 80-84 & -2.858 & 1.306 & -0.124 & 0.130 & -0.081 & -0.879 \\
\hline Dum 84-89 & -3.360 & 0.653 & -0.566 & -0.308 & -0.747 & -1.368 \\
\hline Dum 90-94 & -2.392 & 0.324 & -0.217 & -0.396 & -0.064 & -1.005 \\
\hline Dum 94-99 & -0.729 & 1.496 & 1.287 & $1.007 *$ & $1.560 * *$ & 0.742 \\
\hline Dum 00-04 & $-1.702 *$ & 0.215 & & -0.157 & & -0.512 \\
\hline Dum 05-09 & & 0.785 & 0.210 & 0.552 & $0.776^{*}$ & 0.119 \\
\hline Dum 10-15 & & & 0.628 & -0.137 & 0.255 & -0.070 \\
\hline Lagged Growth & & & & & -0.097 & 0.027 \\
\hline Constant & 1.800 & 0.296 & 2.989 & $2.329 * *$ & 5.371 & $3.820 * * *$ \\
\hline$n T$ & 116 & 176 & 116 & 176 & 90 & 138 \\
\hline
\end{tabular}

Notes: Models (1) and (2) are random-effects specifications and models (3) and (4) are estimated with fixed-effects. Models (5) and (6) are dynamic panels estimated via the Arellano and Bond (1991) procedure. Standard errors are clustered by country and *** and *** denote significance at $10 \%, 5 \%$ and $1 \%$ respectively. 
In this fully specified model (i.e. containing all controls), we again obtain a negative, and highly significant, effect of public debt on economic growth. This value is -0.040 and implies that a $10 \%$ increase in debt accumulation is predicted to lower economic growth by around $0.4 \%$. Thus a country growing at the sample average of $2.9 \%$ would be expected to fall to around $2.5 \%$ if their debt ratio increased for example from $50 \%$ to $60 \%$.

Due to compounding this estimate implies a sizeable national income loss over the medium to longer terms. For instance, if developing Asia's maintained average economic growth rate of five percent per annum could be higher by $0.4 \%$ over the next decade, the volume of developing Asia's output would be 5 per cent higher than otherwise ten years hence

We also conducted diagnostic tests for the fully specified models above. Table 2 presents pvalues for the hypothesis tests described above. In terms of specification tests differentiating between the fixed-effects and random-effects specifications, in both cases we are unable to reject the null of systematic differences in parameters between the two models, and hence are happy to interpret the random-effects estimates alongside those obtained from fixed-effects.

Table 2 - Diagnostic Checks - Panel Data Models

\begin{tabular}{|c|c|c|c|c|}
\hline Test & Model (1) & Model (3) & Model (5) & Model (6) \\
\hline Hausman-Wu & 0.9830 & 0.7681 & & \\
\hline $\operatorname{AR}(1)$ & & & 0.0058 & 0.0182 \\
\hline $\operatorname{AR}(2)$ & & & 0.3738 & 0.6713 \\
\hline Sargan OverID & & & 0.0505 & 0.1014 \\
\hline
\end{tabular}

Notes: The table presents p-values for (i) Hausman-Wu specification tests for differences in parameters for Model (1) and Model (3) as compared to their counterparts Models (2) and (4). Also presented are p-values for autocorrelation tests for dynamic models (5) and (6) and over identification tests on the same models. 
Our serial correlation tests for the dynamic models in models (5-6) are both in-line with our assumptions requiring the presence of $\mathrm{AR}(1)$ errors but not $\mathrm{AR}(2)$. Thus this aspect of the modelling is satisfied. The over-identification checks provided by the Sargan statistics indicate no significant signs of incoherent instrumentation at $5 \%$ for the fully specified model (model (5)), and none at any standard level for the parsimonious specification in model (6).

The dynamic model that found a significant link between public debt and economic growth may be criticised for being over-identified. However, if re-run replacing the annual dummies with a trend, the Sargan statistic from this regression is not rejected (with a p-value of 0.184) and the estimate of $\gamma$ is -0.035 , which is significant at standard levels.

\section{Conclusion}

Developing Asia has been the main engine of global economic growth since the turn of the century. This paper has examined what impact public debt, which increased significantly in the region post GFC, especially in China, has had on that growth. Our estimates imply that a $10 \%$ increase of public debt is associated to the decrease of economic growth between 0.2 to 0.4 percent. If taken as causal, the upper limit of this estimate implies that over the next decade, the volume of Asian output would be around 5 per cent lower, a substantial national income loss over that time.

The policy implication from this study is the need of prudent public debt management to ensure the negative effect of public debt on economic growth in the region does not worsen in the future. In particular, governments in developing Asian economies will need to borrow more selectively to ensure extra public debt is matched by high quality public spending. Meanwhile, scope exists for strengthening budgetary institutions and practices to minimise fiscal risk. 


\section{References}

Antonakakis, N. 2014. "Sovereign Debt and Economic Growth Revisited. The Role of (Non-) Sustainable Debt Thresholds" Vienna University of Economics and Business Working Paper 187.

Arellano, M., \& Bond, S. 1991. "Some Tests of Specification for Panel Data: Monte Carlo Evidence and an Application to Employment Equations." The Review of Economic Studies, 58(2): 277-297. doi:10.2307/2297968

Barro, R. J. 1996. "Determinants of Economic Growth: A Cross-Country Empirical Study." National Bureau of Economic Research Working Paper Series 5698. doi:10.3386/w5698

Barro, R. J., \& Sala I. Martin, X. 1992. "Public Finance in Models of Economic Growth." The Review of Economic Studies, 59(4): 645-661. doi: $10.2307 / 2297991$

Checherita-Westphal, C., \& Rother, P. 2012. "The impact of high government debt on economic growth and its channels: An empirical investigation for the euro area." European Economic Review, 56(7): 1392-1405.

Eberhardt, M., \& Presbitero, A. F. 2015. "Public debt and growth: Heterogeneity and non-linearity." Journal of international economics, 97(1): 45-58.

Égert, B. 2015. "Public debt, economic growth and nonlinear effects: Myth or reality?" Journal of Macroeconomics, 43: 226-238.

Feenstra, R. C., Inklaar, R., \& Timmer, M. P. 2015. "The Next Generation of the Penn World Table." American Economic Review, 10(105): 3150-3182.

Ghosh, A. R., Kim, J. I., Mendoza, E. G., Ostry, J. D., \& Qureshi, M. S. 2013. "Fiscal fatigue, fiscal space and debt sustainability in advanced economies." The economic journal, 123(566): 4-30. doi:10.1111/ecoj.12010

Herndon, T., Ash, M., \& Pollin, R. 2014. "Does high public debt consistently stifle economic growth? A critique of Reinhart and Rogoff." Cambridge Journal of Economics, 38(2): 257-279. doi:10.1093/cje/bet075

Kumar, M. S., \& Woo, J. 2015. "Public Debt and Growth.” Economica, 82(328): 705739. doi:10.1111/ecca.12138

Lopes da Veiga, J. A., Ferreira-Lopes, A., \& Sequeira, T. N. 2016. "Public Debt, Economic Growth and Inflation in African Economies." South African Journal of Economics, 84(2): 294-322. doi:10.1111/saje.12104

Owusu-Nantwi, V., \& Erickson, C. 2016. "Public Debt and Economic Growth in Ghana Public Debt and Economic Growth in Ghana." African Development Review, 28(1): 116-126.

Pescatori, A., Sandri, D., \& Simon, J. 2014. "Debt and growth: is there a magic threshold?" IMF Working Papers 1434.

Presbitero, A. F. 2012. "Total Public Debt and Growth in Developing Countries." The European Journal of Development Research, 24(4): 606-626.

Reinhart, \& Rogoff. 2010. "Growth in a Time of Debt." The American Economic Review, 100(2): 573.

Taylor, A. M. 1995. "Growth and Convergence in the Asia-Pacific Region: On the Role of Openness, Trade and Migration." National Bureau of Economic Research Working Paper Series 5276. doi:10.3386/w5276 